\title{
CHARACTERISTICS OF HUMAN RESOURCES MANAGEMENT MODEL IN PUBLIC ADMINISTRATION OF REPUBLIC OF SERBIA: CONTEMPORARY TRENDS AND CHALLENGES *
}

\author{
UDC $351 / 354$ \\ 331.101 .262
}

\section{Igor Vukonjanski}

Faculty of Law, University John Naisbitt, Belgrade, Serbia

\begin{abstract}
Human resources management in the public administration of the Republic of Serbia is a combined model of good practices from the European administrative area and the remaining stereotypes from pre-transition period. Introduction of the public servant system with all features of contemporary public servant related legislation was a necessity that accompanied overall reform of the public administration in Serbia. The process of introducing human resources management function in the Serbian public administration has been encumbered with application of two different legal models that define the status of public servants: public servant related legislation is applied to employees in executive branches of the central government (ministries, government departments and offices), and the status of employees in city and municipal administrations is stipulated in obsolete laws, adopted over 20 years ago. It should be noted that employees in public sector are still prone to old habits in their work, which altogether reduces successful reforms in this area. This paper provides a description of the current state of affairs and opens certain questions: whether the modern human resources (HR) management in Serbia's public sector is understood and accepted in the right way; and whether it is possible, by means of applying
\end{abstract}

Received February $20^{\text {th }}, 2018 /$ Accepted February $21^{\text {st }}, 2019$

Corresponding author: Igor Vukonjanski, Associate Professor, Faculty of Law, University John Naisbitt,

Belgrade, Serbia; e-mail: ivukonjanski@naisbitt.edu.rs

* The analysis of the situation in the field of public sector, the views and recommendations presented in this paper are the result of many years of work on projects of national importance and specialist training at institutes and academies for public administration in Germany, the Czech Republic, Ireland, Austria, Italy and Sweden. The most important projects in which the author participated and formulated his views expressed in this paper are: (2016) Analysis and description of the situation in the public sector Republic of Serbia: "Coordination for public sector cohesion of the future" (COCOPS); (2014) "Reform of state administration and strengthening of institutional capacities in the Republic of Serbia - second phase; (2012) "Analysis of the competencies and organization of work of ministries, special organizations, government services and professional services of administrative districts and changes; (2009) "Functional Analysis of State Administration Bodies" conducted by the Ministry of State Administration and Local Self-Government within the state administration reform project and (2007) "Decentralization and Strengthening of Local Self-Government" Project of the European Commission and Council of Europe IPA. 
specific methods, to strengthen awareness of public employees concerning their actual position and responsibility to establish a new public administration, adjusted to the citizens' needs, requirements and expectations. Relying on a decade-long personal engagement in this field, the author analyzes the current circumstances and provides critical remarks and recommendations.

Key words: Republic of Serbia, public sector, public servant law, human resources management, analysis, recommendations

\section{INTRODUCTORY REMARKS}

The legal status of public servants from the perspective of common European standards has been defined in the Council of Europe Recommendation no. $\mathrm{R}(2000) 6^{\mathrm{c}}$ oncerning the status of public officials in Europe ${ }^{1}$. Introduction of public servant legislation in the Republic of Serbia's legal system is directly related to the public administration reform and the basic objectives proclaimed in the reform strategy, including decentralization, depoliticization, professionalization and modernization.

The legal frame for development of the public servant system, introduction and application of modern human resources management principles in state administration bodies was created by adoption of the Public Servants Act (2005) and accompanying bylaws. In spite of the apparent progress in the Serbian public administration system, the practice gives a general impression that newly established system of human resources management is inefficient and complicated. Also, there is an impression that the entire process is complete only in legislative terms, while practical solutions in line with modern standards are still pending.

There are new considerations stemming from the specific circumstances where the mechanisms for a full-fledged development of public servant system by means of affirmation, monitoring and evaluating the work of public employees, the system of their professional development and training are still pursued. Public administration employees daily encounter ample internal challenges (complexity and importance of their tasks) and external challenges (growing expectations of citizens who perceive public administration as a service provider)

Considering the incomplete normative framework in this area, there are relapses into old (bureaucratic) habits in providing services, indicating that reform processes in Serbia's public administration have not been completed. Apart from that, certain delays in the course of further improvement of public administration system can be observed. Only six years after the Public Servants Act took effect, enthusiasm and the quality of public administration work have dropped.

There is a founded presumption that the reform makers somewhat lost the opportunity to include other important factors such as motivation and readiness of public employees to support changes in this field, on top of declarative support to the professionalization of public administration as one of its guiding principles, foreseeing the creation of welltrained, responsible and efficient administration. Therefore, it may be concluded that that

\footnotetext{
${ }^{1}$ Recommendation no. R (2000) 6 concerning the status of public officials in Europe (Adopted by the Committee of Ministers on 24 February 2000 at the 699th meeting of the Ministers' Deputies) provides guidelines for EU member states in establishing the legal position of public officials by defining their specific labor status.
} 
public servant system reform is not entirely complementary with other segments of the public administration reform, such as technological modernization, for instance.

Moreover, it is evident that this dynamic process of securing modern, professional, competent, depoliticized and responsible public administration in the Republic of Serbia is not entirely defined, which causes serious obstacles in its work. Besides, there is an impression that there is no awareness in our environment about the premise that the human resources are the most important and the most precious resource. Thus, there is still a sense of a strong need to develop human resources management function to attain competency at all levels of human resources management and personnel development in line with strategic objectives and actual needs of the Serbian state administration.

The existing legislation on the position of public employees is in manifold ways a precious foundation for achieving the listed objectives. The Public Servants Act and accompanying bylaws may truly be declared as reform regulations, having regard that they contribute to a creation of common awareness on significance of the public servant system. Circumstantially, practice points out to existing problems and creates an obligation to address former issues and incomplete answers in new legal provisions which will offer new options and solutions. This will eventually contribute to restoring true dignity of public employees and further affirmation of public employee service as a kind of a social privilege.

\section{Public Servant System in the PUblic Administration of the RePUblic OF SeRbia}

Since its inception and throughout its development, the Serbian administrative tradition had the characteristics of the Austrian public administration model. This model was accepted and applied during the Kingdom of Yugoslavia (1929 - 1941). Although not belonging to democratic political systems, the Socialist Federative Republic of Yugoslavia (SFRY) kept the same features and built up a state administration that could have been considered similar to modern European administrations, owing to its federative structure and developed international cooperation. In that regard, being an heir of such tradition, Serbia presently has potentials to swiftly and successfully adapt its public administration to the market conditions and pluralistic political model.

The tradition where public employees take up special place in the establishment and functioning of the Serbian state dates back to the past, and the public administration system in the Republic of Serbia has almost two centuries long tradition. Specifics of the public servant system in the course of development of the Serbian state were subject to special laws from two reasons. First, the special work regime, responsibilities and privileges of public employees were a consequence of the oligarchs' needs to control their work. Second, the specific order of that system was actually related to the nature of activities conducted by the public servants.

The public servant systems were subject to special laws in the Principality of Serbia at the beginning of the XIX century, ${ }^{2}$ in the Kingdom of Yugoslavia at the turn from the XIX to the XX century, ${ }^{3}$ as well as during the 50 years of the socialist realism dominance. ${ }^{4}$

\footnotetext{
${ }^{2}$ The first legal frame governing the public servant status may be found in the first Serbian Constitution of the Principality of Serbia, adopted in 1835. Chapter XII of that Constitution defined the position of the public servant. The second Serbian Constitution, adopted in 1838, also contained special provisions on public servants. It is believed that the 1838 Constitution of the Principality of Serbia and the 1844 Civil Code made preconditions for the creation of an independent class of public servants. More than 20 years later, the 1861
} 
A new public servant system in the Republic of Serbia is a "Merit-based" career system. The main principles governing the career system of public servants were established by applying the rules on: political neutrality and impartiality; accountability; equal accessibility of workplaces; promotion in service; protection of public servants' and appointees' rights; prohibition of privileges or denials; responsibility for disobedience to the duty; flexible allocation of public servants; servants' right to professional development; their right to organize in trade unions; and the code of ethics for public servants. ${ }^{5}$ Thus, the public servant system in the Republic of Serbia comprises an entire set of logically linked categories, where workplaces and public employees are differentiated according to previously established criteria, which make the basis for their rewarding and the frame for their mobility in the service.

The issues related to public servants are of highest importance due to their significant role in democratic societies, and primarily in establishing, consolidating and preserving democratic institutions. A general trend in the public administration reform provides for the high professional and moral profile of public employees and accountability of all working in the public sector.

\section{RELATIONSHIP BETWEEN GENERAL LABOR REGULATIONS AND PUBLIC SERVANT REGULATIONS}

In almost all countries that make "the European administrative area", labor relations in the state bodies of authority are regulated by separate laws, where the work regime of public servants is significantly different from the work regime in the general labor relations. ${ }^{6}$ In some countries, however, the public administration is regulated with other instruments - traditional regulations, collective or individual agreements. Also, the term "law" should be understood in its broadest sense, including decisions made by the Government, as well as unwritten legal principles and judicial practice. In some areas of public administration in the Republic of

Law on Public Servants by the Prince Regent Mihajlo Obrenovic introduced significant changes in regulating the position and role of the public servants. The 1888 Constitution of the Kingdom of Serbia also regulated the position of public servants, in the Chapter named "The State Service".

3 The 1923 Public Servants Law, adopted in the Kingdom of Serbs, Croats and Slovenians, for the first time regulated the public servant system according to the principles known to us today. The Law precisely defines the many issues in the area of public servant legislation, and legal provisions defining public servant relations were imperative, empowering and constitutional. The Public Servant Law of 1931 went even further; the most significant provisions regulated the first basis of cadre policy, mechanisms to limit employment, promotion of state servants, and some limitations related to the state service.

${ }^{4}$ The legal system of the "post-war" Yugoslavia also contained the public servant system, which was functional in various modalities until the adoption of the 1966 Labor Relations Act, which made the formerly adopted 1957 Public Servants Act ineffective. The Yugoslav public servant system in the traditional sense was abandoned during the period in between the Constitution of the Federative Republic of Yugoslavia of 1963 and the Constitution of the Federative Republic of Yugoslavia of 1974, when the ideological concept of workers' self-governance in economy and state administration was introduced. After the dissolution of the Socialist Federative Republic of Yugoslavia in 1991, the Republic of Serbia introduced the Act on Labor Relations in Public Administration Bodies, which as a lex specialis regulated the legal and labor position of employees in public administration bodies.

5 See: Principles of Public Administration, CSO SIGMA, http://www.sigmaweb.org/publications/PrinciplesPublic-Administration-Nov2014.pdf, and Law on Civil Servants from 2006, amended in 2009, 2009 and 2017.

6 According to the Latin legal proverb "lex specialis derogat legi generali", the law defining the position of public servants prevails over the law regulating general labor issues. It means that labor relations in public administration are regulated by the special law, and not by general labor regulations that govern only some issues which are not regulated by special laws on state servants. 
Serbia, the position of public servants is additionally regulated by special laws that respect the specific characteristics of individual sectors of the executive government. ${ }^{7}$

The essential difference between labor law and public servant law in the Republic of Serbia is that labor law is based on cooperation between employers and employees, while public servant law is based on the relationship of the state towards the public servant. While labor law is based on individual labor relations involving cooperation and negotiation on rights and duties, public servant law is based on administrative relations defined by a unilateral administrative act adopted by a state body. Consequently, labor law is lex generalis, and public servant law is lex specialis, given that public servant relations are a special form of labor relations.

There are different perspectives and opinions concerning the public servant relations as a special type of relation between the public servant and the state, as an employer. The Serbian expert literature contains diverse opinions on the classification of the public servant law. According to some theorists, the public servant law falls within a subgroup of administrative legislation. Other theorists do not perceive public servant relations to be an administrative type of relation, but rather to be a pure labor relation where the person in public service has the same employment rights as any other employed persons. Serbian practice concludes that the public servant relations are of statutory character since this issue has been defined by the law and not by employment contract. ${ }^{8}$ On the other hand, according to the Public Servants Act (2005) of the Republic of Serbia, the public servants relations are perceived as a type of labor relations whereas, when it comes to state employees and not the appointees, the permanent feature is that the public servant relation contains special and extremely emphasized public law elements. The regulation of the normative status of public servants, as the essential part of public administration, is significant considering the authority stemming from their status.

Having in mind that the public servant system in the Republic of Serbia was created as a compilation of the basic principles of the public servant system and general labor regulations, the entire concept is subordinated to the definition of a term "public servant", which in principle refers to all persons who perform public administration activities within a state or public administration body as their regular, permanent and main profession. The public servants conduct their administrative, professional and other duties in line with the Constitution, the law and other regulations; the scope of activities and specific competences required for performing these duties are prescribed by the internal administrative acts of the public administration body where they are employed. Therefore, the public servants are not Members of Parliament, President of the Republic, members of the Government, the Supreme Court Judges, judges, public prosecutors and deputees, nor other persons appointed by the National Parliament or Government, or persons appointed to functions in line with special regulations. In the most general sense, in the Republic of Serbia, public servants are all persons employed in government bodies, whose workplaces imply direct or

\footnotetext{
${ }^{7}$ In Serbian legislation, the special public servant system includes: the police, army, foreign affairs, customs, tax administration, and penalty institutions.

${ }^{8}$ The Sebian Public Servants Act prescribes that the rules, obligations and responsibilities of public servants shall be defined by the law and bylaws. If such special law or other regulation does not provide for certain labor issues related to public servants, the general labor regulations apply.

${ }^{9}$ The term "public servant" is one of the most disputed issues in the theory of administrative, labor and public servant law.
} 
indirect participation in the implementation of competencies assigned according to the public rights and responsibilities to protect general interest of the state.

\section{CHARACTERISTICS OF THE HUMAN RESOURCES POLICY IN THE PUBLIC ADMINISTRATION OF THE REPUBLIC OF SERBIA}

The human resources (HR) policy is an essential segment within the public servant system in the Republic of Serbia, which is defined as an activity aiming to create respective cadre preconditions for the work of the public sector. This activity is synchronized with three objectives: achieving maximum effectiveness of the public administration; enabling optimum development and professional improvement of public servants; and creating a sense of respective status security and satisfaction among employed servants. According to the set objectives, the HR policy is implemented in three segments: affairs related to reception of suitable human resources in the service and rotation of servants to specific work places; affairs related to professional training and provision of assistance in personal development of public servants during their work in service; and affairs related to creating optimal work conditions for public servants. ${ }^{10}$

The HR policy should aim towards exclusion of inadequate, incompetent or unworthy public servants. Besides, there are activities to attract the most competent staff to the state service, and activities related to staff rotation in workplaces according to the needs of the state bodies, but also in line with personal characteristics of an employee. The basic principles for employment of public servants are equality in accessing state service and competence to work in state service. These principles are supported through a process of fair and open competition.

Within the public servant system of the Republic of Serbia, there are structured elements of selection to the state service, which relate to the needs of an administrative body for human resources of specific profession, required competencies and respective personal characteristics of candidates applying to the state service. In addition to general conditions (such as adequate educational background, Serbian citizenship, nonconviction, etc.), an important requirement is the capacity to work in the state service, in particular the candidate's intellectual ability.

In addition to aforementioned passive selection of applicants for state administration, active mechanisms of follow up, analysis and recording interested candidates have been insufficiently promoted. Such mechanisms are supported solely through internal competitions to fill up vacancies, making a de facto contribution to the implementation of career system for public servants. Since the mechanism to attract human resources from external labor market has not yet taken hold in the public administration of the Republic of Serbia, this area is in need of further normative and procedural regulation.

Besides weaknesses observed in the field of HR policy in the Republic of Serbia, activities have been taken in order to create conditions for quality selection, quality empowerment to work in public administration, and introducing incentives for improving overall efficiency and effectiveness of work towards creating a new image of public servants. The expected results lean towards providing quality professionals capable to

\footnotetext{
${ }^{10}$ These principles are derived from the study by J.Schwarze: "European Administrative Law, London, 1992, according to the OCDE document (SIGMA/PUMA (99) 44:" Principles of europeens d'administration publigue, Sigma, No. 27.
} 
strengthen administrative capacities eventually, primarily by changing the personal attitude towards work.

Further on, HR policy completes other designated tasks aimed at creating and profiling specific human resources for the public administration. This is primarily related to an autonomous process for acquiring knowledge, obtaining professional experience and personal improvement initiated and implemented by an individual to bring his/her work to a highest possible level. Organizational models of creating and profiling human resources carried out by public administration bodies proved to be a necessary assistance to an individual in his/her pursuit to define and implement personal career advancement goals.

The current circumstances in the public HR policy in the Republic of Serbia point out to an insufficient awareness and acceptance of the fact that building and strengthening institutional capacities of the public administration is a precondition to successfully implement the reform processes. Professionalization as a relevant precondition for creating well-trained, responsible and efficient administration is currently implemented only through professional development system for public employees and development of recruitment and employment system in the state administration bodies. Other segments of the HR management still do not necessarily have a strategic role in the creation of depoliticized and professional public administration. Such systemic weakness is particularly reflected in the implementation of career system in public administration, as well as in concrete issues such as: evaluation and promotion, professional development, salary system, and strategic planning of resources ${ }^{11}$ in the public administration of the Republic of Serbia.

The key weaknesses of the country's public servant system are: inexistence of needs assessment concerning current HR needs and functional forecast of HR needs, attracting HR from the external labor market, quality planning of trainings to provide knowledge, skills and competencies needed for a more efficient achievement of work results.

In order to overcome such a state of affairs in the Serbian public administration, the HR planning should be based on: 1) a report on accomplished work results of a state body in the previous period; 2) a plan with estimates of technological and organizational changes; 3) assessment of internal and external HR mobility; 4) analysis of skills, knowledge and performance of existing human resources; and 5) appraisal of risks that could jeopardize plans.

Partly justifying the unsatisfactory condition in Serbia's public administration HR policy, we may outline that state bodies are structured as considerably "closed" organizations, with a very low interaction with the external labor market. The best indicator to support this is the following situation: when a vacancy needs to be filled in, a public body first has to announce an internal competition; the public body may seek for a candidate by public announcement on the external job market only if the vacancy has not been filled from internal HR resources. In practice, external recruitment lasts between six months and one year, which additionally hampers the process and makes the rotation mechanism lose its purpose. ${ }^{12}$

\footnotetext{
${ }^{11}$ During job classification, it is evident that executives in state bodies concentrate only on satisfying short-term needs for HR, neglecting long-term organizational plans. Such disconnected way of planning is of reactive character, inefficient and detrimental in long term as regards efficiency of state administration as a whole.

${ }^{12}$ An indicator of introversy of a public administrative body is a very low fluctuation of employees. To date experience reflects that workforce mobility has not been a primary mechanism to ensure HR in Serbia's public administration. Valid data from 2008 show that recruitment was carried out for 794 vacancies. In 2009 recruitment was done for 686 vacancies, resulting in 341 filled vacancies. Upon public competition, 305 vacancies were filled, while only 36 vacancies were filled after internal competition. The data include ministries, special organizations and government
} 
Considering all the above, HR policy in the public administration of the Republic of Serbia fulfils its role primarily by creating preconditions for: 1) horizontal mobility of public servants within public administration system; 2) compulsory mobility, i.e. rotation of public servants in line with requirements and needs of the service; and 3) promotion of public servants to a higher position based on personal abilities and achieved work results.

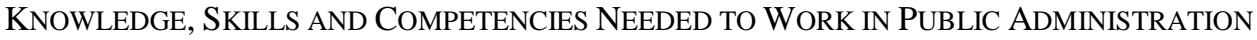 OF THE REPUBLIC OF SERBIA}

A general occurrence in all transition countries is an insufficient number of quality candidates, fully equipped to work in state administration. In the current circumstances and with given procedures, it is very difficult to ensure a selection and employment process exclusively based on professional references and personal potentials. Therefore, uniform employment methodology needs to be improved, which would structure the reception process in state administration bodies, starting from the needs for a specific job, establishing the professional profile of an "ideal" candidate, the announcement of public advertisement, the interview with candidates, testing and check the candidates' practical knowledge, evaluation, and final selection of an "ideal" candidate. This is the only way to promote affirmative selection principle in the course of recruitment for public administration, eventually leading to the selection of the most competent people for vacant positions.

As public servants are expected to have other knowledge and skills ${ }^{13}$ on top of the educational background and work experience, candidates interested in having a long-term career in the public sectors should meet the following requirements: 1) ability to comprehensively access the organization and development in a state body; 2) active participation in daily work; 3) high level of personal integrity, impartiality and ethics; 4) ability to manage personal potentials rationally; 5) adjustable and flexible reaction to all changes in work environment; 6) endurance when performing under stress; 7) proactive attitude towards the development of professional knowledge and skills; and 8) clear perception of one's career development. ${ }^{14}$

As it is realistic to expect that candidates for public administration vacancies will not be able to show all the required skills, quick learning potential is sufficient. Besides, the candidates need to display a minimum of capacity needed to carry out the job they apply for.

Given the mentioned HR deficit of personnel with requisite skills and competencies that make them good candidates for work in the public administration of the Republic of Serbia, the public administration system needs to pay special attention to the existing employees. In that regard, it is essential to create preconditions to improve professional

services. Data are not included in the Ministry of Defense and the Ministry of Internal Affairs, as well as the Security and Information Agency, as records of personnel are kept in these bodies (Human Resource Management Service; http://www.suk.gov.rs/en/about_us/competence)

${ }^{13}$ These skills include: communication skills in both written and oral form; manual/technical skills, including computer skills; administrative organization; planning and management of one's own work; social skills; intellectual capacity and personal skills-ability to work independently, decision making, adaptability to new conditions, etc.

${ }^{14}$ The requirements are contained in the following OECD documents: Trustees in Government-Ethic Measures in OECD Countries; OECD, 2000; Transparency International Source Book 2000 - Confronting Corruption: The Elements of a National Integrity System, Berlin, 2000; Principles for the management of ethics in the public service - OECD Recommendation; PUMA policy brief No. 4, May 2008. 
qualifications of the existing public servants. The only way to achieve this is to establish a quality system of professional development. ${ }^{15}$

Several situation factors go in favor of professional development. On the one hand, it is a necessity to increase professionalization level, so that public employees are able to adjust and respond to new requirements set before the executive branch of the government. On the other hand, the imperative to rationalize or reduce the number of state servants creates a requirement for a smaller portion of public employees to carry out the task given to a state administration body. In such a constellation of systemic and situational factors, ongoing quality professional development becomes one of the key factors for efficient work of public servants.

Based on this approach, practical assessment of professional development of public servants is based on the following criteria: workplace requirements; characteristics of workplace and management functions; strategic objectives and annual operational plans of public administration; and problems identified in the work of state bodies related to professional knowledge and skills of public servants. ${ }^{16}$

Additional reasons why it is necessary to invest into additional education and permanent professional development of public servants are related to the fact that formal educational system in the Republic of Serbia can no longer independently respond to all requirements of a modern and dynamic state administration. Moreover, in the system where public servants acquired education in various educational systems, changes in the work methodology and technology in public administration require new knowledge and skills, and diminishing the existing educational differences.

Some statistical information obtained by the government's professional development directorate may be of interest. Among public servants who attend trainings and courses, the most frequent participants are women $(71 \%)$, while men take the remaining $29 \%$. The average age of a public servant who attends trainings is 44.6 years, while the age sample ranges from 21 to 64 years. Further on, statistical data show that average duration of work experience held by attendees is 11.06 years. ${ }^{17}$ According to the type of jobs conducted by the public servants, the most represented ones are the jobs in the financial, analytical and legal sector. In the public servant trainings, line managers are represented with only $21.3 \%$, while the most represented line managers are of the lowest rank - task force managers with $82 \%$. The chiefs of departments are represented with $14 \%$, while the heads of sections make only $4 \%$ out of the total number of line managers attending trainings for public servants. ${ }^{18}$

Although $73 \%$ of public servants thinks that there are changes in their work after attending a seminar, the largest number of respondents $(40 \%)$ think that participation in seminars had a positive effect on their motivation to carry out regular work (to a large

\footnotetext{
${ }^{15}$ The common types of public servants education include: 1) computer literacy training, 2) courses in foreign languages, and 3) specialized trainings tailored to specific scope of work of the respective state bodies.

16 HRM Challenges were addressed in the Project: Human Resources Management System in Public Administration in Serbia - Basic Analysis and Training, UNDP, published in the publication "Human Resource Development Management"), December 2009.

${ }^{17}$ Out of $63 \%$ of public servants who expressed the need for future development, the most represented are those working in the state bodies for less than 10 years. Almost $12 \%$ of public servants with over 20 years of service in the public administration expressed no intention to attend trainings in the forthcoming period. (Project: "Human Resources Management System in Public Administration in Serbia - Basic Analysis and Training", UNDP, published in the publication "Human Resource Development Management", December 2009).

${ }^{18}$ Project: "Human Resources Management System in Public Administration in Serbia - Basic Analysis and Training“, UNDP, published in the publication "Human Resource Development Management", December 2009.
} 
extent $9 \%$, considerably $31 \%$, relatively $39 \%$ ), while only $9 \%$ of respondents think that participation in seminars was insignificant for their work motivation, and $7 \%$ of respondents did not notice significant motivational change. ${ }^{19}$

In order to increase the quality and effectiveness of professional development, it is necessary to act based on the following presumptions: 1) to bring professional development from fragmented to systematic approach; 2) to base training programs on realistic needs of a workplace, i.e. the public body; 3) to make professional development objectives much more defined; 4) trainings should contribute to a real increase of professionalism and acquiring new skills; 5) to base special professional development programs on special strategies in line with challenges and problems encountered in the work of a public administration body; 6) to analyze changes in the scope of public administration body that require special professional development of employees; 7) to hold every public servant accountable for his/her professional development, where he/she will identify the specific needs for professional development together with his/her immediate manager; 8) HR units should take proactive stance towards evaluation of programs, contents and methods of professional development, trainings and courses, by sending feedback on the quality of completed trainings; and 9) professional development should be supported and promoted by high officials, which entails acknowledging the significance of professional development both for public servants and for the state authority.

\section{OUTCOMES OF CURRENT CHANGES AND WAYS TO FUTURE DEVELOPMENT OF THE PUBLIC SERVANT SYSTEM IN THE REPUBLIC OF SERBIA}

In the past period, the biggest challenges faced by the state administration of the Republic of Serbia have been: the creation of public administration in the service of citizens; the public administration's ability to proactively respond to requests coming from society and the global environment; ability to respond to new organizational requirements; ongoing adjustment to new challenges of decentralizing administration and EU integration of the Republic of Serbia.

Contrary to the experiences of some Central and Eastern European countries, the Republic of Serbia had "an automatic transfer" of all employees in state bodies into a prestigious status of public servants, which resulted in certain consequences which are present even today. Since the Republic of Serbia missed an opportunity to create a professional elite comprising truly and essentially depoliticized public servants, it is rightfully expected that the public servant system would compensate and correct this within, by using all available internal mechanisms.

The necessary preconditions for a systemic resolution of the public servants' status in Serbia's public administration have been met, by means of instituting equality of candidates in the employment process, supporting professional career development in the state bodies, affirmation of the system for developing employees' professional skills and

\footnotetext{
${ }^{19}$ The research has shown that $89.3 \%$ of respondents are positive towards the influence of trainings on their interest for further professional development, while $7.5 \%$ think that trainings influenced their interest to a smaller extent. Only $3.2 \%$ of the interviewees think that trainings did not have any effect on their further professional development. In the surveyed sample, women showed more interest in professional development then men. (Project: "Human Resources Management System in Public Administration in Serbia - Basic Analysis and Training“, UNDP, published in "Human Resource Development Management", December 2009).
} 
competencies, establishing the new HR management policy, instituting a flexible frame for organizing work in public administration bodies, and establishing a new culture in public administration as a response to the needs of the society.

The results achieved in Serbia's public administration to date show the level of accomplishing the proclaimed objectives and priorities, and clearly indicate the need for further and overall reform and reorganization of public administration. Although the achieved results are not minor, it is evident that they could be higher and more prominent.

In the course of further public administration reform, a lot of effort should be invested and a range of measures and concrete steps have to be conceptualized and implemented, which should finally result in abandoning the traditional organization and operative practices in public administration, based on conservative and traditional bureaucratic procedures, which make the state administration inefficient, too expensive and alienated from the citizens, and thus considerably inacceptable to the general public.

Although adopting a new legal frame in the field of Serbia's public servant system is a very important step in the public administration reform, fair and consistent implementation of the adopted legal acts in the field is a much harder and more demanding task. Besides, it is necessary to adopt a number of regulations pertaining to public servants in the local selfgovernment units, which currently do not fall within the public servant system. Labor positions of employees in the local executive branch should be defined in line with positive experiences of the public servant system at the central level.

The law regulating the position of officers in the local self-governmentis ${ }^{20}$ only a normative framework. In essence, the position of officers in the local self-government units has not improved. New systematics of vocations and payroll coefficients were introduced, but in practice only simple translations into the new status came. New titles are equated with ranks of previous titles. The same was achieved with the salary system. Also, examples of the vertical mobility of officers from local self-government units to the organs of the central executive authority are the "statistical error" points. Professional training of employees in local self-government units is at the same level as before, and all activities carried out by the National Academy for administration are at an early stage. ${ }^{21}$

As the managerial approach is expected to create a development environment following the vision, mission and strategic development plans of the state bodies, career management of public servants has to become a crucial element of the HR policy. In that sense, it is necessary to: 1) create a system to attract and retain young and creative staff; 2) encourage innovations in the work process and facilitate conditions for their implementation; 3) reward new ideas that contribute to improvement of the work process; 4) create conditions for permanent development of public employees; and 5) create a reliable system of continued career advancement. ${ }^{22}$

Besides, HR managers are expected to recognize the potential of each and every employee, to evaluate employee's competencies, to propose job rotations suitable for a public servant, to spot missing competencies or skills, to propose trainings for strengthening

\footnotetext{
${ }^{20}$ See: Law on Employees in Territorial Autonomy Authorities and Local Government Units from 2016

${ }^{21}$ The National Academy of Public Administration was established in 2017. At the moment, only $35 \%$ of jobs are filled, and they carry out their activities in other business premises. The total number of trainings for 2017 is only 208 training for 4103 employees. Source: www.napa.gov.rs/

${ }^{22}$ Government of the Republic of Serbia (2014): Public Administration Reform (PAR)Strategy in the Republic of Serbia, for the period 2015-2017; Government of the RS (2015): Action Plan for Implementation of the Public Administration Reform Strategy in the Republic of Serbia; https://www.srbija.gov.rs/dokument/ 45678/strategije.php
} 
those competencies, and to be directly responsible for trainings and professional development of the subordinate public servants. In that direction, additional efforts should be made to link the central institution for professional development (National Academy of Public Administration) in association with university centers. Additionally, it is necessary to work on the massiveness of the program of professional development of officers and linking this process with career progression.

The public servant system in the Republic of Serbia at this stage does not clearly envisage mandatory support to public servants to ensure their productivity and better work results, nor does it have considerable effect on their professional development and career guidance. ${ }^{23}$ Such activities, if any, are primarily inspired by practical requests to achieve better work results. In such circumstances, the public servants who have a precise vision of their career development goals and ambitions often experience hindrance, frustration and denial, all of which ultimately hampers their essential motivation - to serve the community.

\section{CONCLUSION}

Today, public servants in the Republic of Serbia are expected to meet ample requirements of their workplace and to respond to the requests of their managers. In turn, their managers are expected to provide a minimum of working conditions for their subordinates, where they will be able to demonstrate their professional and work skills. Improvement of HR management also means creating an optimal environment where often hidden potentials will come to the forefront.

The public servant system in the Republic of Serbia, based on the integrated principles of political neutrality, impartiality, public servant ethics, equal job accessibility, career advancement, labor protection of public servants, prohibition of privileges or denial of rights, flexible allocation of public servants, and the right to professional career development through the promotion system, is in compliance with the basic characteristics of the public servant legislation in the countries of the European Administrative Area.

Yet, almost fifteen years after the Public Servants Act took effect, we may still observe a transitional dimension in the development of Serbia's public servant system. This circumstance points to a number of unresolved problems deriving from inconsistent application of regulations, lack of professionalism in managers, and absence of clear political will to completely develop a professional and depoliticized public servants' system.

As a special message of this text, there is a necessarily fully identifiable position of officials in the central and local organs of execution. As the work of the executive power is unique, the position of civil servants must be identical.

\section{REFERENCES}

Armstrong, M.(2006). Handbook of Human Resource Management Practice, $10^{\text {th }}$ edition, Kogan Page.

Ebbesson, J. (2002). Access to Justice in Environmental Matters in the European Union, Kluwer, The Hague London - New York.

\footnotetext{
${ }^{23}$ Here, first of all, is meant the administrative reduction of salaries, the inability to progress on the basis of annual performance assessments and insufficient capacities for professional improvement, which are available at the National Academy of Public Administration.
} 
Ketelaar, A. (2007). Improving Public Sector Performance Management in Reforming Democratizers, Newsletter DAIdeas.

Schwarze, J. (1992). European Administrative Law, London, 1992, according to the OCDE document (SIGMA/PUMA (99) 44: Principles of europeens d'administration publigue, Sigma, No. 27.

Vidlakova, O. (1998). Regulatory Reform in OECD. In: Public Administration, Brussels

European Commission: Federal Republic of Yugoslavia, Country Strategy Paper 2002-2006, http://arhiva.emins. org/uploads/useruploads/dokumenti/030729-csp2002-2006.pdf

Government of the Republic of Serbia, Human Resource Management Service; http://www.suk.gov.rs/en/about_us/ competence.dot

Recommendation no. R (2000) 6 concerning the status of public officials in Europe, adopted by the Committee of Ministers on 24 February 2000 at the 699th meeting of the Ministers' Deputies.

Recommendations for administrative reform of the Republic of Serbia (2001), International Conference OECD, Paris

SIGMA (2014), The Principles of Public Administration, OECD Publishing, Paris; http://www.sigmaweb.org/ publications/Principles-Public-Administration-Nov2014.pdf

UNDP/RBEC: Rebuilding State Structures: Methods and Approaches. United Nations Development Programme, Hlohovec, Slovakia, 2001.

UNDP Project: Human Resources Management System in Public Administration in Serbia - Basic Analysis and Training“, UNDP, published in the publication "Human Resource Development Management"), December 2009.

Vlada Republike Srbije (2014), Strategija reforme javne uprave u Srbiji za period 2015-2017 (Public Administration Reform (PAR) Strategy in the Republic of Serbia for the period 2015-2017); Vlada Republike Srbije (2015),Akcioni plan za sprovođenje Strategije reforme javne uprave u Republici Srbiji za period 2015-2017 (Decision No. 021-3092/2015 on the Action Plan implementing the PAR Strategy in the Republic of Serbia for the period 2015-2017); https://www.srbija.gov.rs/dokument/45678/strategije.php; http://mduls.gov.rs/propisi/strategije/

Zakon o državnim službenicima (Civil Servants Act), Službeni glasnik RS, br. 79-2005,81-2005-ispr., 83-2005ispr., 64-2006-ispr., 116-2008, 104-2009, 99-2014, 94-2017 i 95-2018; https://www.paragraf.rs/propisi/ zakon_o_drzavnim_sluzbenicima.html

\section{SPECIFIČNOSTI MODELA UPRAVLJANJA LJUDSKIM RESURSIMA U JA VNOJ UPRAVI REPUBLIKE SRBIJE POMORSKE PRIVREDE - SAVREMENI TRENDOVI I IZAZOVI -}

Upravljanje ljudskim resursima u javnoj upravi Republike Srbije predstavlja kombinovani model dobre prakse zemalja evropskog administrativnog prostora $i$ stereotipa koji su se zadržali iz predtranzicionog perioda. Uvođenje službeničkog sistema sa svim obeležjima savremenog činovničkog prava bila je nužnost koja je pratila sveukupnu reformu javne uprave u Republici Srbiji.

Proces uvođenja funkcije upravljanja ljudskim resursima u javnoj upravi Repblike Srbije opterećen je okolnostima da se na sve zaposlene u javnoj upravi primenjuju dva različita zakonska modela koji uređuju njihov status - na zaposlene u centralnim organima izvršne vlasti (ministarstva, službe $i$ kancelarije Vlade) primenjuje se činovničko pravo, a položaj zaposlenih u upravama gradova i opština uređen je zastaraelim zakonima koji su doneti pre 20 i više godina. Treba istaći $i$ to da zaposleni $u$ javnom sektoru i dalje podležu starim navikama u svom radu što sve skupa umanjuje uspešnost uvođenja promena u ovoj oblasti.

Ovaj rad pruža opis postojećeg stanja u ovoj oblasti i otvara određena pitanja: da li je savremeno upravljanje ljudskim resursima u javnom sektoru Republike Srbije shvaćno i prihvaćeno na pravi način, $i$ da li je moguće primenom određenih metoda kod zaposlenih ojačati svest o njihovom realnom položaju $i$ realnoj odgovornosti za uspostavljanje nove javne uprave prilagođene potrebama, zahtevima $i$ očekivanjima građana. Autor teksta svoju analizu postojećeg stanja, kritički osvrt i preporuke zasniva na ličnom decenijskom angažovanju u ovoj oblasti.

Ključne reči: Republika Srbija, javni sektor, činovničko pravo, upravljanje ljudskim resursima, analiza, preporuke 